\title{
MYCOBACTERIA IN AQUARIUM FISH: ARE FISH HANDLERS AWARE OF THEIR ZOONOTIC POTENTIAL?
}

\author{
Mateja Pate ${ }^{1 *}$, Andrej Ovca², Vlasta Jenčič ${ }^{1}$, Manca Žolnir-Dovč ${ }^{3}$, Matjaž Ocepek ${ }^{1}$ \\ ${ }^{1}$ University of Ljubljana, Veterinary Faculty, Gerbičeva 60, 1000 Ljubljana, ${ }^{2}$ University of Ljubljana, Faculty of Health Sciences, Zdravstvena \\ pot 5, 1000 Ljubljana, ${ }^{3}$ University Clinic of Respiratory and Allergic Diseases Golnik, Golnik 36, 4202 Golnik, Slovenia
}

${ }^{*}$ Corresponding author, E-mail:mateja.pate@vf.uni-lj.si

\begin{abstract}
Mycobacteria potentially pathogenic for humans are commonly present in aquarium fish sold in Slovenian pet shops. Mycobacterium marinum is the most important causative agent of skin mycobacteriosis in humans. The purpose of the present study was to evaluate, by means of a questionnaire, aquarium hobbyists' and pet shop salespersons' awareness of the health risks related to aquarium fish handling.

A total of 198 participants took part in the study, $76.3 \%$ of these were aquarium hobbyists, and $23.7 \%$ were pet shop salespersons with up to 15 years of fish handling experience. About one third (35.8\%) of all participants recognized that fish may be a source of infection for humans and that fish may contract tuberculosis. Fewer (24.4\%) were aware of the fact that fish tuberculosis is a zoonotic disease. The vast majority of respondents were unfamiliar with the clinical manifestations of either fish tuberculosis or cutaneous mycobacteriosis in humans. Despite the generally acknowledged belief that aquarium water may pose arisk to human health, the respondents' aquarium handling practices were surprising as the majority never used waterproof gloves.

Several differences were revealed between the two groups of respondents. Pet shop salespersons were better educated on fish handling, and more were aware of the health risks linked to aquarium fish than aquarium hobbyists. The latter often perceived pet shop salespersons as relevant sources of information. However, overall awareness of the zoonotic potential of fish mycobacteria proved to be fairly low. Therefore, more effort should be made to increase the awareness of the role of mycobacteria in infections associated with exposure to aquarium fish.
\end{abstract}

Key words: fish tank granuloma; fish tuberculosis; mycobacteria; questionnaire; zoonosis

\section{Introduction}

Fish are the third most popular pet globally, owned by $12 \%$ of more than 27,000 respondents in an international pet ownership survey (1). With increasing fish popularity, owners should be sensitized to public health issues related to handling aquarium fish. Fish tank water hosts highly diverse microbial communities, including pathogens which pose a potential risk to the pet industry, fish in trade, and humans (2). Several

Received: 7 May 2018

Accepted for publication: 22 February 2019 pathogens associated with aquarium fish are zoonotic and may be transmitted to humans through cuts or abrasions of the skin and through direct contact via bites, stings, and spine or pincer injuries. The epidemiology of aquarium fish related infections is complex as fish may often act as asymptomatic carriers transmitting the pathogens to humans, commensal microbes may become zoonotic pathogens, and clinical manifestation of the disease in fish may have little relevance to clinical signs in affected humans (3). Groups at risk include individuals frequently exposed to fish, their products, or their environment and persons with impaired immune systems. 
Bacteria are the primary causative agents of zoonotic infections related to aquarium fish, and mycobacteria are probably the best known zoonotic fish-borne pathogens. Three mycobacterial species most commonly associated with fish disease are Mycobacterium (M.) marinum, $M$. fortuitum, and M. chelonae. However, a variety of other nontuberculous mycobacteria (also called mycobacteria other than tuberculosis, atypical, opportunistic, or environmental mycobacteria) reported in humans have also been associated with fish mycobacteriosis (4). The disease is usually systemic, characterised by granulomas in multiple organs or tissues. The affected fish show no specific clinical signs until the appearance of overt symptoms such as scale loss, pigment changes, emaciation, ulceration, and behavioural changes. In addition to fish, mycobacteria can infect a number of other aquatic organisms and can replicate in various protozoan hosts (5).

In humans, fish-borne or water-borne mycobacterial infection leads to superficial granulomatous inflammation, most commonly seen on the extremities; however, deeper tissues may also be involved. The localized form of the disease presents with nodular or ulcerated lesions while the sporotrichoid form is associated with lymphatic spread (6). Although rare, disseminated infections have mostly been described in immunocompromised patients (7) but have also been reported in immunocompetent persons (8). Diagnosis of skin mycobacteriosis (also called fish tank/swimming pool granuloma or fisherman's/fish-fancier's finger) is difficult due to its nonspecific and insidious presentation; therefore, a delay in diagnosis is commonly observed $(9,10)$. Once diagnosed, the infection can be effectively treated with antibiotics although surgical intervention may sometimes be required (6).

Surveys on the presence of mycobacteria in aquarium fish from pet shops in Slovenia indicated a high level of contamination with mycobacteria, potentially pathogenic for humans. M. marinum was detected in $20.7 \%$ and $10.6 \%$ of mycobacteriapositive fish, respectively $(11,12)$. Fish tank granuloma is rarely detected in humans in Slovenia; only 12 cases have been reported from 2000 through 2018 in a population of approximately two million (M. Žolnir-Dovč, unpub. data). Nevertheless, the disease is very likely underdiagnosed.

The purpose of the present study was to evaluate the awareness of aquarium hobbyists and pet shop salespersons of the health risks associated with aquarium fish handling.

\section{Material and methods}

To evaluate the awareness of aquarium hobbyists and pet shop salespersons of the health risks associated with aquarium fish, participants were invited to complete an anonymous questionnaire developed by the authors. The questionnaire was comprised of 20 questions on fish-related training, fish, and aquarium waterhandling practices, knowledge of fish tuberculosis and fish tank granuloma, as well as possible personal experiences with the infections. The questionnaire was first tested on a pilot group of 10 people with fish handling and/or questionnaire development experience to determine question clarity, identify additional response options, and to assess the length of time necessary to provide answers. The questionnaire was revised accordingly. The data was evaluated and analysed using the Statistic Program for the Social Sciences (SPSS, Version 24.0).

\section{Results}

A total of 198 respondents participated in the study $(28.3 \%$ men, $71.1 \%$ women, mean age 26 years, age range 12 to 69 years). Of these, $76.3 \%$ were aquarium hobbyists (AH) and $23.7 \%$ were pet shop salespersons (PSS) with up to 15 years of fish handling experience. The two groups of respondents differed in several factors.

The majority of the respondents (84.8\%) had no special fish-related education, i.e., attendance of specialised courses or lectures. However, PSS were better trained (23.4\%) than $\mathrm{AH}(2.7 \%)$. When asked about self-education, only $35.5 \%$ of the respondents reported reading literature with website publications being the most common source of information, followed by books and advice from PSS. There was a statistically significant difference $(\mathrm{p}<0.001)$ between $\mathrm{AH}$ and PSS; $25.3 \%$ of the former and $68.1 \%$ of the latter reported reading literature for self-educational purposes.

Regarding knowledge of the zoonotic nature of fish diseases, only $35.8 \%$ of the respondents were positive that some fish diseases could be transmitted to humans, while $53.4 \%$ of the respondents were unsure of this possibility. 
Table 1: Summary of answers related to the respondents' knowledge of fish tuberculosis and fish tank granuloma

\begin{tabular}{lccccccc}
\hline \multicolumn{1}{c}{ Answer } & \multicolumn{2}{c}{ Yes } & \multicolumn{2}{c}{ No } & & I do not know & $\begin{array}{c}\text { Fisher's } \\
\text { exact test }\end{array}$ \\
\hline \multicolumn{1}{c}{ Statement/query } & $\begin{array}{c}\text { PSS } \\
(\%)\end{array}$ & $\begin{array}{c}\text { AH } \\
(\%)\end{array}$ & $\begin{array}{c}\text { PSS } \\
(\%)\end{array}$ & $\begin{array}{c}\text { AH } \\
(\%)\end{array}$ & $\begin{array}{c}\text { PSS } \\
(\%)\end{array}$ & $\begin{array}{c}\text { AH } \\
(\%)\end{array}$ & p value \\
\hline $\begin{array}{l}\text { Some aquarium fish diseases } \\
\text { can be transmitted to humans }\end{array}$ & 69.6 & 52.6 & 5.0 & 16.0 & 24.5 & 4.1 & $<0.001$ \\
\hline $\begin{array}{l}\text { Aquarium fish may contract } \\
\text { tuberculosis }\end{array}$ & 73.9 & 24.5 & 6.5 & 4.8 & 19.6 & 70.7 & $<0.001$ \\
\hline $\begin{array}{l}\text { Fish tuberculosis-causing } \\
\text { bacteria may be dangerous to } \\
\text { human health }\end{array}$ & 56.5 & 14.3 & 6.5 & 8.8 & 37.0 & 76.9 & $<0.001$ \\
\hline $\begin{array}{l}\text { Aquarium water may be a } \\
\text { source of harmful microbes } \\
\text { causing human infection }\end{array}$ & 84.8 & 71.4 & 2.2 & 0.7 & 13.0 & 27.9 & 0.059 \\
\hline $\begin{array}{l}\text { Are you familiar with clinical } \\
\text { signs of fish tuberculosis? }\end{array}$ & 32.6 & 4.1 & 67.4 & 95.9 & $/$ & $/$ & $<0.001$ \\
\hline $\begin{array}{l}\text { Are you familiar with clinical } \\
\text { signs of fish tank granuloma? }\end{array}$ & 2.2 & 3.4 & 97.8 & 96.6 & $/$ & $/$ & 1.000 \\
\hline
\end{tabular}

†PSS, pet shop salespersons; ${ }^{\circledR} \mathrm{AH}$, aquarium hobbyists

Table 2: Recommended precautions to prevent the transmission of fish tuberculosis $(17,18)$

\begin{tabular}{|c|c|}
\hline Recommendation & Description \\
\hline $\begin{array}{l}\text { Buy healthy fish from trust- } \\
\text { ed suppliers }\end{array}$ & $\begin{array}{l}\text { Healthy fish have smooth, sleek, shiny scales, and intact fins. Fish bodies } \\
\text { should not have any bumps or lesions. }\end{array}$ \\
\hline $\begin{array}{l}\text { Monitor the health status of } \\
\text { fish daily }\end{array}$ & $\begin{array}{l}\text { Symptoms of illness may include abnormal swimming, scale loss, coloration } \\
\text { changes, lack of appetite, loss of body weight, skin ulcers, eroded fins, belly } \\
\text { swelling. } \\
\text { If a fish looks sick, place it in a tank by itself to prevent other fish in the main } \\
\text { aquarium from getting sick. } \\
\text { Immediately remove any dead fish from the aquarium to reduce the risk of } \\
\text { spreading the disease to other fish. } \\
\text { Consult a veterinarian specialized in fish diseases. }\end{array}$ \\
\hline
\end{tabular}

Do not release unwanted fish Never release aquarium fish into any waterway. into nature

Do not dispose of water or sick fish into storm-water or street drains.

By following these recommendations, you will help to preserve the health of free-range and cultured aquatic animals.

Dispose of dead fish safely Put dead fish into a plastic bag and place them in the waste that is not intended for recycling.

\begin{tabular}{ll}
\hline $\begin{array}{l}\text { Dispose of aquarium tank } \\
\text { water safely }\end{array}$ & $\begin{array}{l}\text { Pour the aquarium waste water down a household sink. } \\
\text { Do not use kitchen or bathtub sinks. } \\
\text { Do not use the waste water to water house or garden plants. }\end{array}$
\end{tabular}

Follow good hygiene practice Wash hands before and after feeding the fish. Help children feeding the fish to wash their hands thoroughly.

Do not allow children younger than five to come into contact with aquarium water and fish.

Do not allow people with impaired immune system to clean the aquarium. When cleaning the aquarium, always wear waterproof gloves which should completely cover the parts of the arms immersed in water.

Use utensils intended for aquarium cleaning only.

Pay attention to your health If you notice skin lesions characteristic of skin mycobacteriosis, consult your physician and make sure to mention that you have a pet fish. 
Similarly, $36.3 \%$ of the respondents confirmed that fish may contract tuberculosis, with a notable difference $(\mathrm{p}<0.001)$ between PSS and AH $(73.9 \%$ vs. $24.5 \%)$. However, only $24.4 \%$ of the respondents agreed that the bacteria causing fish tuberculosis might endanger human health. Again, a higher awareness of this fact was notable among PSS (56.5\% agreed) compared to $\mathrm{AH}(14.3 \%$ agreed) (Table 1).

Furthermore, $10.8 \%$ of the respondents claimed that they could recognise clinical signs of fish tuberculosis (among them, PSS showed a statistically significant predominance over AH: $32.6 \%$ vs. $4.1 \%$ ), while only $3.1 \%$ had ever heard of fish tank granuloma (Table 1). The majority of the respondents also denied ever having had cutaneous lesions resembling the lesion presented in a photograph on the questionnaire.

Considering the general belief expressed by $74.6 \%$ of the respondents, that aquarium water may contain microbes harmful to humans, their aquarium handling practices were surprising, as the majority $(74.6 \%)$ never used waterproof gloves when cleaning the aquarium or handling fish.

\section{Discussion}

To the best of our knowledge, the present study is one of a very few published surveys on the awareness of zoonotic potential of fish mycobacteria. The findings presented herein support previously reported observations that fish handlers' awareness of aquarium fish related health risk is poor. A French nationwide study, including 40 pet shop salespersons, revealed that $75 \%$ of the respondents knew little or nothing about skin mycobacteriosis in humans and $52.5 \%$ knew little or nothing about the disease in fish (13). On the other hand, when the knowledge and experience in terms of fish tuberculosis were assessed among the members of three tropical fish clubs in the United Kingdom (14), $60 \%$ of the respondents claimed that they could probably (or definitely) recognize fish tuberculosis. However, only $30 \%$ were aware of the risk of skin infection after contact with fish.

We have demonstrated the high level of contamination of aquarium fish with mycobacteria, which are potentially pathogenic to humans, in our previous studies $(11,12)$. Ornamental fish sold in pet shops in Slovenia mostly originate from fish farms in southeast Asia and are imported either directly from the country of origin or through distribution centres in Europe. Therefore, we believe that the presence of mycobacteria in aquarium fish in Slovenia reflects a global state in the ornamental fish industry. Other studies have also reported high proportions of mycobacteria positive aquarium fish $(15,16)$. Considering the rising number of people with weakened immune system, raising the awareness among fish handlers is essential to prevent mycobacterial infections, particularly since fish handling practices have been found to be risky as the majority of the respondents never used waterproof gloves when cleaning aquariums or handling fish. These findings correlate with previous reports. Of the 40 respondents included in a study by Gray et al. (14), 85\% immersed their hands at least once a week in the fish tanks, and only two (5\%) ever wore gloves. Similarly, Schmoor et al. (13) reported that 95\% of the aquarium fish salespersons cleaned the aquariums without wearing gloves and $65 \%$ handled dead fish with bare hands. A total of $90 \%$ of salespersons immersed their unprotected hands into the aquariums on a daily basis.

There is another aspect to consider. The present study revealed that the respondents to the questionnaire most often disposed of aquarium waste water by pouring it into the sink/toilet (83\%, data not shown). Authorities recommend disposing aquarium tank water into household sinks and not into street or storm-water drains in order to prevent the transmission of pathogens into the environment $(17,18)$. It should, however, be noted that not all household sinks are appropriate for waste water disposal. Some respondents reported using the kitchen or bath sinks, which present risky practices. Cases of mycobacterial infections in young children have been described where fish tanks were cleaned in bathtubs in which children were also bathed $(19,20)$. In order to follow good hygiene practices at home, it is also inappropriate to dispose of aquarium waste water in areas devoted to food preparation. The use of separate supplies and tools, intended for aquarium cleaning alone, is highly recommended.

In conclusion, PSS demonstrated a higher level of knowledge and more appropriate fish handling practices. They were also perceived as a relevant source of information for $\mathrm{AH}$ and tended to be more aware of fish tuberculosis and its zoonotic potential. Nevertheless, poor general knowledge 
of the clinical manifestations of fish tuberculosis and fish tank granuloma was demonstrated. Efforts should, therefore, be made to increase awareness of the role of mycobacteria in infections associated with exposure to aquarium fish. A step in this direction was taken by publishing a leaflet describing the disease in fish and humans along with the precautions needed to prevent infection. The leaflet was distributed to the public on several occasions and is available (in Slovenian only) at https://www.vf.uni-lj.si/si or from the corresponding author upon request. In addition, an excerpt from the leaflet, related to the recommended precautions, is presented in Table 2 to give an overview of the preventive measures that aquarium fish handlers may introduce into their daily practices.

\section{Acknowledgements}

We thank Lidija Gnidovec, Majda Golob, Darja Kušar, Jelka Zabavnik Piano, and Damijana Kastelec for their support in data collection.

\section{References}

1. GfK. Pet ownership internationally (2016). [Accessed 2018, March 28]. Retrieved from http:/ / www.gfk.com/global-studies/global-studies-pet-ownership/

2. Smith KF, Schmidt V, Rosen GE, Amaral-Zettler L. Microbial diversity and potential pathogens in ornamental fish aquarium water. PLoS One 2012; 7(9): e39971. doi: 10.1371/journal.pone.0039971

3. Lowry T, Smith SA. Aquatic zoonoses associated with food, bait, ornamental, and tropical fish. J Am Vet Med Assoc 2007; 231(6): 876-80. https://doi.org/10.2460/javma.231.6.876

4. Gauthier DT. Bacterial zoonoses of fishes: a review and appraisal of evidence for linkages between fish and human infections. Vet $\mathrm{J}$ 2015; 203(1): 27-35. https://doi.org/10.1016/j. tvj1.2014.10.028

5. Gauthier DT, Rhodes MW. Mycobacteriosis in fishes: a review. Vet J 2009; 180: 33-47. doi: 10.1016/j.tvj1.2008.05.012

6. Lewis FM, Marsh BJ, von Reyn CF. Fish tank exposure and cutaneous infections due to Mycobacterium marinum: tuberculin skin testing, treatment, and prevention. Clin Infect Dis 2003;
37: 390-7. https://doi.org/10.1086/376628

7. Streit M, Böhlen LM, Zimmerli S, Tscharner GG, Nievergelt H, Bodmer T, et al. Disseminated Mycobacterium marinum infection with extensive cutaneous eruption and bacteremia in an immunocompromised patient. Eur J Dermatol 2006; 16: $79-83$.

8. Vazquez JA, Sobel JD. A case of disseminated Mycobacterium marinum infection in an immunocompetent patient. Eur J Clin Microbiol Infect Dis 1992; 11: 908-11.

9. Edelstein H. Mycobacterium marinum skin infections: report of 31 cases and review of the literature. Arch Intern Med 1994; 154: 1359-64. doi:10.1001/archinte.1994.00420120079009

10. Dolenc - Voljč M, Žolnir - Dovč M. Delayed diagnosis of Mycobacterium marinum infection: a case report and review of the literature. Acta Dermatovenerol Alp Pannonica Adriat 2010; 19: 35-9.

11. Pate M, Jenčič V, Žolnir - Dovč M, Ocepek M. Detection of mycobacteria in aquarium fish in Slovenia by culture and molecular methods. Dis Aquat Org 2005; 64: 29-35. https://doi. org/10.3354/dao064029

12. Kušar D, Zajc U, Jenčič V, Ocepek M, Higgins J, Žolnir-Dovč M, et al. Mycobacteria in aquarium fish: results of a 3-year survey indicate caution required in handling pet-shop fish. J Fish Dis 2017; 40(6): 773-84. https://doi. org/10.1111/jfd.12558

13. Schmoor P, Descamps V, Bouscarat F, Grossin M, Belaich S, Crickx B. Les connaissances et le comportement des vendeurs de poissons exotiques concernant la " maladie des aquariums" (Tropical fish salesmen's knowledge and behaviour concerning "fish tank granuloma"). Ann Dermatol Vénéréol 2003; 130: 425-7.

14. Gray SF, Smith RS, Reynolds NJ, Williams EW. Fish tank granuloma. Br Med J 1990; 300: 1069-70.

15. Prearo M, Zanoni RG, Campo Dall'Orto B, et al. Mycobacterioses: emerging pathologies in aquarium fish. Vet Res Commun 2004; 28: 315-7.

16. Zanoni RG, Florio D, Fioravanti ML, Rossi M, Prearo M. Occurrence of Mycobacterium spp. in ornamental fish in Italy. J Fish Dis 2008; 31: 433-41. doi: 10.1111/j.1365-2761.2008.00924.x

17. Biosecurity materials for ornamental fish. Canberra : Department of Agriculture and Water Resources, Australian Government, last reviewed

12. April 2019. http://www.agriculture.gov. au/pests-diseases-weeds/aquatic/disease_ 
watch_aquatic_animal_health_awareness /other_ aquatic_biosecurity_materials (28. March 2018)

18. CDCP. Healthy pets, healthy people. Pets \& other animals. Fish. Atlanta : Centers for Disease Control and Prevention, last reviewed 1. Oct. 2015. https://www.cdc.gov/healthypets/pets / fish.html (28. March 2018)

19. King AJ, Fairley JA, Rasmussen JE. Dis- seminated cutaneous Mycobacterium marinum infection. Arch Dermatol 1983; 9: 268-70.

20. Parent LJ, Salam MM. Appelbaum PC, Dossett JH. Disseminated Mycobacterium marinum infection and bacteraemia in a child with severe combined immunodeficiency. Clin Infect Dis 1995; 21: 1325.

\title{
MIKOBAKTERIJE PRI AKVARIJSKIH RIBAH: ALI SE AKVARISTI ZAVEDAJO NJIHOVEGA ZOONOTSKGA POTENCIALA?
}

\author{
M. Pate, A. Ovca, V. Jenčič, M. Žolnir-Dovč, M. Ocepek
}

Povzetek: Za ljudi potencialno patogene vrste mikobakterij so v Sloveniji splošno prisotne pri akvarijskih ribah, ki so naprodaj v trgovinah z domačimi ljubljenčki, med drugimi tudi vrsta Mycobacterium marinum, ki je najpomembnejša povzročiteljica kožne mikobakterioze pri ljudeh. Namen raziskave je bil, s pomočjo vprašalnika, oceniti zavedanje ljubiteljskih akvaristov in prodajalcev v trgovinah z akvarističnim programom o zdravstvenih tveganjih, povezanih z rokovanjem z ribami.

V raziskavi je sodelovalo 198 oseb, 76,3\% ljubiteljskih akvaristov in 23,7\% prodajalcev v trgovinah, ki so v povprečju imeli do 15 let izkušenj pri rokovanju z akvarijskimi ribami. Približno tretjina (35,8 \%) sodelujočih se je strinjala s trditvijo, da so ribe lahko vir okužbe za ljudi in da ribe lahko zbolijo za tuberkulozo. V manjšem deležu (24,4\%) so se sodelujoči strinjali s trditvijo, da je ribja tuberkulozazoonoza. Velika večina anketirancev ni poznala kliničnih znakov ribje tuberkuloze in kožne mikobakterioze priljudeh. Kljub splošno izraženemu prepričanju, da lahko voda iz akvarija predstavlja tveganje za zdravje ljudi, je bila splošna praksa rokovanja z ribami presenetljiva, saj velika večina sodelujočih pri rokovanju z ribami nikoli ne uporablja vodoodpornih rokavic.

Med obema skupinama anketirancev smo odkrili več razlik. Prodajalci v trgovinah so bolj poučeni o rokovanju z ribami in bolj ozaveščeni o zdravstvenih tveganjih povezanih z akvarijskimi ribami, kot ljubiteljski akvaristi. Slednji prodajalce dojemajo kot zaupanjavreden vir informacij. V splošnem je ozaveščenost o zoonotskem potencialu mikobakterij priakvarijskih ribah precej slaba, zato bi morali nameniti več pozornosti ozaveščanju o vlogi mikobakterij pri okužbah, povezanih zakvarijskimi ribami.

Ključne besede: kožna mikobakterioza; ribja tuberkuloza; mikobakterije; vprašalnik; zoonoza 